\title{
A case for subgenera in a foraminiferal classification
}

D. Graham Jenkins

Department of Earth Sciences, Open University, Milton Keynes, U.K.

There has been a progression in palaeobiological classifications from the more primitive empirical "stamp collecting"stage where similar shapes were grouped together, to the more sophisticated phylogenetic classifications where supposed genetically related foraminiferal taxa are categorised together. But how do we know that certain extinct taxa were genetically related? This is a major problem where a number of factors interplay together: a belief in evolution, the experience of the operator and consequent recognition of phyletic lineages. In the study of Cenozoic planktonic foraminifera we are fortunate to have recognised a number of now well established lineages; also we have some data on amino-acids found in the tests of living species (King and Hare, 1972) which range back well into the Neogene. These latter data not only provide us with essential genetic information but they also give us confidence when dealing with the classification of extinct species.

So how do we build this evolutionary knowledge into a classification? Clearly, genetically related species can be grouped together into subgenera, and related subgenera into broader genera. In their classification Loeblich and Tappan (1988) held a different view and decided not to use subgenera because (1) their usage produces an unwieldy classification, and (2) lineage concepts change when additional data are collected. If we follow their classification, then when you read about Globorotalia menardii, Globorotalia fohsi and Globorotalia hirsuta you could assume that they are closely related; this is not true. The three species have similar test morphologies but these have resulted from iterative evolution in the Neogene. Thus $G$. menardii is a descendant of the Lower Miocene G. praescitula, $G$. fohsi is descended from the Lower Miocene $G$. peripheroronda and $G$. hirsuta is descended from $G$. scitula which originated in the Middle Miocene (Kennett and Srinivasan, 1983, Cifelli and Scott, 1986).

In order to sort out this mess, Bandy (1972) produced subgenera and so we have G. (Menardella) menardii, $G$. (Fohsella) fohsi and G. (Hirsutella) hirsuta. If you find this unwieldy then it can be reduced to $G$. (M.) menardii etc. The argument about the use of subgenera is about communication versus obscurantism.

As for lineage concepts changing, this again is a false argument. The $G$. $(F$.) fohsi lineage was first described by Bolli (1950) and although some workers such as Blow and Banner (1966) have split off and consequently added new subspecies, the lineage remains unchanged; the lineage starts with $G .(F)$ peripheroronda and ends at the top of the Middle Miocene with the extinction of $G$. $(F$.$) robusta. This is a neat,$ compact and well understood lineage and the same can be said for Menardella and other subgenera of the Neogene Globorotalia. Additional data can be easily incorporated into the lineages as they become available.

If you do not like subgenera, then they could be upgraded to genera. But Loeblich and Tappan (1988) refused to do this with Menardella, Fohsella and Hirsutella, and preferred instead to synonymise them out of existence under Globorotalia. The basic problem with the Loeblich and Tappan(1988) classification of foraminifera is that it is not phylogenetic: it is a catalogue of genera grouped together into suprageneric categories. The revision of their 1964 Treatise classification (Loeblich and Tappan, 1964) missed a golden opportunity: it should have been a collaborative work of the many experts who are working on the different groups of foraminifera. I believe that other revisions of the Treatise are of this nature.

\section{REFERENCES}

Bandy, O. L. 1972. Origin and development of Globorotalia (Turborotalia) pachyderma (Ehrenberg). Micropaleontology, $\mathbf{8}$, $294-318$.

Blow, W. H., and Banner, F. T. 1966. The morphology, taxonomy and Biostratigraphy of Globorotalia barisanensis LeRoy, Globorotalia fohsi Cushman and Ellisor, and related taxa. Micropaleontology 12, $286-302$.

Bolli, H. M. 1950. The direction of coiling in the evolution of some Globorotaliidae. Contr. Cushman Found. Foram. Res. 1, 82 - 89.

Cifelli, R., and Scott, G. 1986. Stratigraphic record of the Neogene Globorotalia radiation. Smithsonian Contributions to Palaeobiology, No. 58, p. 1 - 101.

Kennett, J. P. and Srinivasan, M. S. 1983. Neogene planktonic foraminifera. Hutchinson Ross Publ. Comp. p. 1 - 265.

King, K. Jr. and Hare, P. E. 1972. Amino acid composition of the test as a taxonomic character for living planktonic Foraminifera. Micropaleontology 18, 285 - 293.

Loeblich. A. R. and Tappan, H. 1964. Sarcodina, chiefly "Thecamoebians" and Foraminifera, in R. C. Moore (ed.) Treatise on Invertebrate Paleontology, Protista 2, Pt. C. University of Kansas Press p. 900. 